\title{
The adjustment and optimized path of regional industrial structure in low-carbon economy society in China: A case study of Tianjin
}

\author{
Hao Zhenzhen ${ }^{1 \star}$ and Li Jian ${ }^{1,2}$ \\ ${ }^{1}$ Department of Management and Economy, Tianjin University, Tianjin 300072, PR China. \\ ${ }^{2}$ School of Management, Tianjin University of Technology, Tianjin 300072, PR China.
}

Accepted 5 July, 2013

\begin{abstract}
The industrial structure strategy in China has to change to adjust new requirements, because of the economic development, industrial evolution, the policy of energy saving and greenhouse gas emissions constraints. This paper aims to explaining the relationships between the industrial structure and carbon intensity, the regional differences between provinces in China based on recent economic data, including internal industry structure, carbon emissions, industrial carbon productivity in different industry in 2001-2010 in China. The case in this paper mainly focuses on Tianjin, China. In this case, industry influent coefficient and industry carbon emission influent coefficient are measured. Meanwhile, four different categories are divided by measurement values, such as Low-impact and High-Carbon Emission Industry Sectors, Low-impact and Low-Carbon Emission Industry Sectors, High-Impact High-Carbon Emission Industry Sectors, High-Impact Low-Carbon Emission Industry Sectors. The important industry sectors and its development strategy in Tianjin are proposed and the priori analysis to the macroeconomic influence by industrial structure adjustment is given later. The results of priori analysis showed that: the important industry and its development strategy can reduce the carbon emission combining with several policies. The proposed policies in last part of this paper include Industry Sectors Adoption Policy, Industry Layout Policy, Financial Policy, Environment Policy, technology Policy, Energy Efficiency Policy, and Industry Association Policy in the low-carbon development constraints.
\end{abstract}

Key words: Industry structure adjustment, optimized path, industrial influent index, Industrial carbon emission influent index, Tianjin

\section{INTRODUCTION}

The participants of 192 countries have committed themselves to reducing the emotions of carbon dioxide and other green gas to avoid "dangerous interference in the climate system" in the UN climate summit on 7th18th, December 2009 (Gavin and David, 2009); however, the way to realize the above objectives is very difficult for policy-maker around the word. We are moving into the so-called Low-Carbon Economy Age in the world. Low Carbon Economy is a new form of social economic growth, which specialized in technological innovation, system innovation, industrial low-carbon adjustment and new energy development.

Although China has achieved rapid economic growth in recent decades, its policies prefer industrialization and

*Corresponding author. E-mail: tju_zhen@163.com. Tel: (0086)18910890986. 


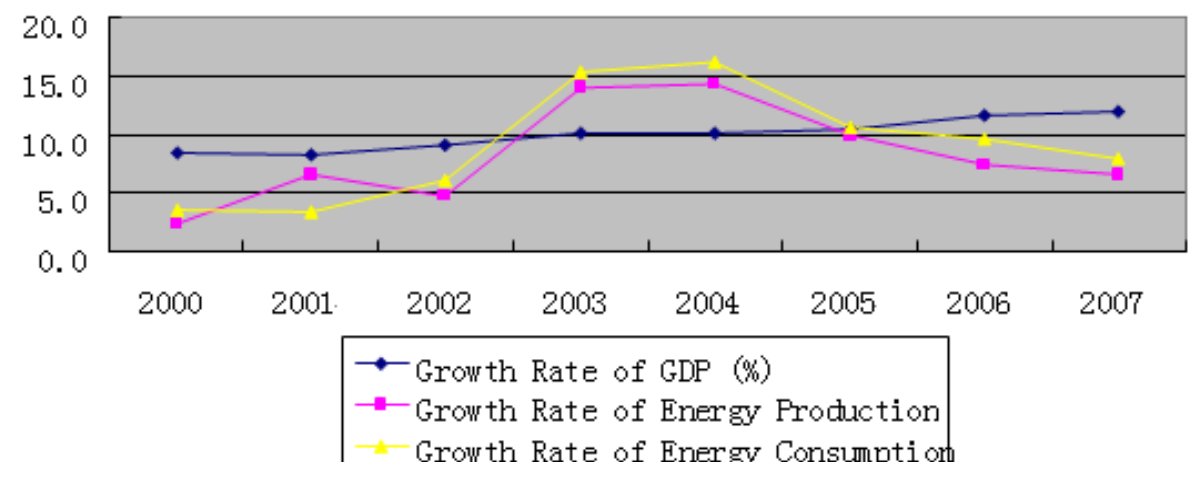

Figure1. GDP, energy production and energy consumption growth rate of China.

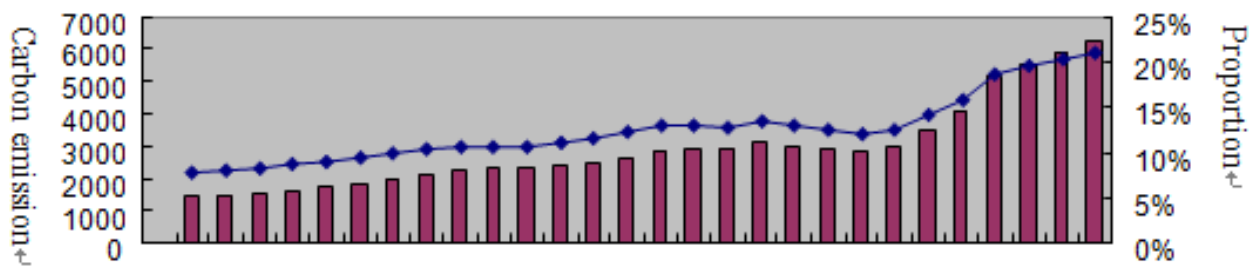

19811983198519871989199119931995199719992001200320052007

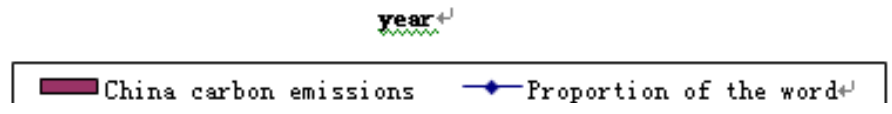

Figure 2. China's carbon emissions and its proportion of the word.

urbanization over environment production, which results in high resource input, high energy consumption, high pollution emission and serious environmental problem. The carbon emission of China shares the one of the word specific weight, $7.89 \%$ in 1981 , but $21.01 \%$ in 2007 . The changing trend is shown in Figures 1 and 2. China faces significant pressure to reduce the emission of greenhouse gases.

It is very necessary to find the effective way to reduce the carbon emission, to fulfill the promise of reducing 40$50 \%$ energy consumption per unit of GDP at the end of 2050 in China. This study aims to examine the adjustment and optimized path of the Chinese industry structure in a joint Low-carbon analysis framework by using correlation analysis, matrix analysis and unique province-level economic and environmental data from 2001 to 2007.

The rest of the paper is organized as follows. Section 2 provides a literature review on the adjustment of industrial structure in low-carbon economy society. Section 3 presents methodology framework and the methods on correlation analysis, matrix analysis. Section 4 shows the data source and results of the provincial relationship between industry structure and carbon emissions, and as a typical old Industry City, Tianjin is chosen for the case study. Section 5 presents the policy enlightenment based on the above analysis.

\section{LITERATURE REVIEW}

In recent years, industry structure adjustment, as a way to release the contradiction between economic growth and environmental protection, has been widely considered by industry policy analysis and decision maker in China. Various existing studies on this topic in social science concentrated in the relationship between economic growth and indexes of environmental quality.

The environmental Kuznets Curve has been widely studied by both theoretical and empirical perspectives; however, the debates on the EKC also gradually increased in recent years. The theoretical analysis can predict an inverted $U$ curve for the dynamic relationship between pollution and economy, but not a fits-all shape curve, because of different data source and various function forms. Yu et al. (2011) studies the relationship between economic development, industrial structure and the carbon emissions, and the results show that there is an "N"-shaped relationship between the carbon intensity and per capita GDP. Still, other scholars studied in this field consistent with the findings that the proportion of 
secondary industry has a positive correlation with carbon intensity, that is, the higher the proportion of secondary industry, the higher the intensity of carbon dioxide emissions, and carbon emission is closely related to the secondary industry. Wang and Wang (2010) uses scenario analysis and the results show that if there is no adjustment of industrial structure and implementation of other policies, economic growth is hard to cause a dramatic decline in carbon intensity, and the target of $\mathrm{CO}_{2}$ intensity discharge $40-50 \%$ in 2020 would be difficult to achieve. And as mentioned in the introduction that industrial structural adjustment needs to be a comprehensive analysis of carbon emissions and the contribution of industry, so this paper explores the different industrial carbon emission ratio and industrial contribution to GDP ratio based on the former scholars' research result, to determine the idea of industrial restructuring.

Many studies have shown that the industry structure adjustment is an important way to reduce the emission of $\mathrm{CO}_{2}$, especially the secondary industry, which is considered as the leading producer of $\mathrm{CO}_{2}$ (Cole, 2008; Panayoto, 1997; Fisher Vanden et al., 2006; Talukdar and Meisner, 2001. The purpose of China's current industrial structure adjustment and transformation is fast and well economy development. As China's market economy is not perfect, recent adjustment of industrial structure is mainly through the central governmentcontrolled industrial fixed assets investment and capacity investment. In 2010, China's State Council promulgated the "Industrial restructuring and Guidance Catalogue (2010)". Wang (2009), in the analysis of the industrial structure of China's industrial conflict, figures out that in China "twelfth five-year" period, the core of the industrial restructuring is to solve our resources and environment problems unsustainable due to the long-term resident in the bottom of the energy value chain. Grossman and Krueger (1995) argued that economic growth affects the environment by expanding the scale of economic activity, altering the industry structure, and improving the techniques of production. Although, some have challenged this assertion (Jorgenson, 2007; Stefanski, 2009). Many Chinese scholars (Shuai and Yuan, 2009; Liu and Feng 2010) study carbon emissions, and the results show that the industrial structure changing can be a good way to reduce the whole society carbon emissions, and industrial structure optimization is an important means of energy saving. But the author through correlation analysis of carbon emissions and industrial structure, using relevant data in 2001-2009, found that carbon emission is related to industrial structure, but the relationship is not strong; meanwhile, there is obvious provincial heterogeneity in different regions of China, even negative correlation at the provincial level panel data. Therefore, consideration of industrial structure through carbon emissions alone is too unilateral.
While energy structure adjustment (reducing the use of primary energy including coal, oil, gas and other high carbon emission energy, developing clean energy, such as wind energy, biomass, solar) also can reduce the emissions of carbon dioxide (Jefferson, 2008), and it helps a lot to promote the achievements of our energy reduction goals (Wei, 2007). However, many studies have confirmed that industrial structural transformation is conducive to energy structure adjustment and energy efficiency. Xu and Jiang (2007) showed that industrial structure changes play the most important role in the improvement of energy efficiency in the United States. Meanwhile, Shi (2002) claimed the similar study in the area of China. However, Lin et al., 2010; Lin and Jiang 2009, a scholar of Chinese Academy of Sciences put forward the opposite view, and he believes that there is little space for China's current emission reduction by changing the energy structure, and we should pay attention to other aspects of energy conservation efforts, such as industrial restructuring. Various kinds of energies possess obvious complementary, for example, high carbon emission energy can be alternated by clean energy. Yet, one industry cannot be substituted by the other one; there have no complementary. For example, the increase of logistics industry does not decrease the amount of oil and chemical industry. Therefore industry structure adjustment must also consider the level of economic development and market demand.

In summary, industrial structure adjustment is an important means for carbon emission reduction, and how to optimize the industrial structure for the better achievement of the carbon emission reduction, while ensuring steady economic development, is a problem worthy to study.

\section{METHODOLOGY}

The methodology framework of this study is mainly focused on correlation analysis and matrix analysis. The relationships between industrial structure and carbon emission among 28 provinces in China are analyzed by correlation analysis; meanwhile, matrix analysis is used to classify the industry sectors of a case to illustrate the key influence of each different category in order to propose special policies on industrial adjustment and optimized path.

\section{Provincial industrial structure}

Provincial Industry structure can be calculated by the proportion of provincial industry output value and gross domestic product. That is,

the provincial industry structure $=\frac{\text { the industry output value }}{G D P \text { in the same year, } \text { same province }}$

The provincial industry output value and China's Gross Domestic Product of 28 provinces spanning from the year 2001 to 2009 are studied in this paper. The data were obtained from China Statistical Yearbook. 
Table 1. Fossil energy conversion coefficient for standard coal.

\begin{tabular}{lccc}
\hline Energy species & Raw coal & Crude & Natural gas \\
\hline conversion coefficient & $0.7143 \mathrm{~kg} \mathrm{S.C./} \mathrm{kg}$ & $1.4286 \mathrm{~kg} \mathrm{S.C./ \textrm {kg }}$ & $1.3330 \mathrm{~kg} \mathrm{S.C.} / \mathrm{kg}$ \\
\hline
\end{tabular}

Data source: China Energy Statistical Yearbook (2009).

Table 2. Various energy carbon emission coefficients.

\begin{tabular}{lccc}
\hline Data source & Coal & Crude & Natural gas \\
\hline Energy Information Administration (EIA) & 0.702 & 0.478 & 0.389 \\
Institute of Energy Economics, Japan & 0.756 & 0.586 & 0.449 \\
$\begin{array}{l}\text { National Development and Reform Commission, } \\
\text { Energy Research Institute, China }\end{array}$ & 0.7476 & 0.5825 & 0.4435 \\
\hline
\end{tabular}

Data source: National Development and Reform Commission, Energy Research Institute, (China).

\section{Estimation of carbon emission}

China's provincial carbon emissions can be estimated using the following formula:

$$
C=\sum_{i} E \times S_{i} \times F_{i}
$$

Where, $\mathrm{C}$ means total carbon emissions; $\mathrm{E}$ means the $\mathrm{i}$-th fossil energy consumption, $S_{i}$ means the i-th fossil energy conversion coefficient of standard coal, $F_{i}$ means the i-th fossil energy carbon emission coefficient .

Fossil energy consumption data are obtained from China Energy Statistical Yearbook, and fossil energy conversion coefficient for standard coal use the values provided in China Energy Statistical Yearbook shown in Table 1. Carbon emission coefficients used in the different organization are not completely identical (Table 2). This paper used these data published by the National Energy Commission.

\section{Industrial influence coefficient}

Defining $A$ is direct consumption matrix, $B$ is for the input-output full demand matrix (Leontief inverse), then

$$
B=(I-A)^{-1}
$$

The industry influence coefficient can be calculated by

$$
\begin{aligned}
& \delta_{j}=\frac{b_{j}}{\sum_{j=1}^{n} b_{j} \alpha_{j}}, j=1,2, \cdots, n \\
& \alpha_{j}=\frac{Y_{j}}{\sum_{j=1}^{n} Y_{j}}, j=1,2,3, \cdots, n
\end{aligned}
$$

Where $\delta_{j}$ means the national economic influence coefficient of industry $j, b_{j}$ means the column sum of matrix $B . Y_{j}$ means the industry's added value. $\alpha_{j}$ means the propriety of added value in Gross Domestic Product (GDP); it expresses the national economic changes by one unit change in industry $j$, reflecting the association of industry $\mathrm{j}$ to the national economy.

\section{Industrial influence coefficient of carbon emission}

This paper defined industrial emissions influence coefficient as the impact on the national economy carbon emissions when there is a unit increase in the industry.

A unit increase in an industry will lead to demand for other industries products, and the products are produced to meet the new demand; hence, there will be more carbon emissions. Therefore, the carbon emissions caused by a unit increase in an industry should be the sum of the volume exhausted by all industries to meet the requirement.

Define $C$ is diagonal matrix composed of carbon productivity of various industries.

$$
C=\left[\begin{array}{cccc}
c_{1} & 0 & 0 & 0 \\
0 & c_{2} & 0 & 0 \\
0 & 0 & c_{3} & 0 \\
0 & 0 & 0 & c_{n}
\end{array}\right]_{n \times n}
$$

Where, $C_{j}$ means the carbon productivity of industry $j$, and $B_{C}=C^{-1} B$, then the carbon emissions caused by a unit increase of industry $j$ can be expressed by the $j$-th column sum of matrix $B_{C}$.

$$
c \delta_{j}=\frac{c b_{j}}{\sum_{j=1}^{n} c b_{j} \times \alpha_{j}}, j=1,2, \cdots, n
$$

Where, $c b_{j}$ is the $j$-th column sum of matrix $B_{C}, \alpha_{j}$ is the 
property of the value-added of various industries in gross domestic product (GDP), $c \delta_{j}$ is the industrial carbon emissions coefficient of industry $j$ influence coefficient, which reflects the industry's carbon emissions impact to the whole national economy when considering the industry association.

\section{CASE STUDY}

Provincial heterogeneity analysis - correlation between the carbon emissions intensity and industrial structure in major provinces

The panel data of China's 28 provinces from the year 2001 to 2008 are analyzed. The correlations between carbon emissions and three major industrial structure are obtained by software SPSS and the Associated Integrated Sequence (Table 3).

The relationship between industry development and carbon emission was examined and the results indicate that two-tailed test of variable association between the three industries and carbon emissions intensity is less than 1\% from the national level, and there is significant correlation between the variables. The order of their correlation is as follows: secondary industry, tertiary industry and primary industry. Carbon emission is very sensitive to the increase of the proportion of secondary industry, and there is a strong positive correlation between them; while there is low sensitivity for primary industry and tertiary industry and a negative correlation. That is, the increase proportion of primary industry and tertiary industry could reduce carbon emissions.

Because of the heterogeneity in economic development and industrial structure in different provinces, there is a huge different correlation between carbon emissions and industrial structure. Industrial structure adjustment should take into account of the regional difference in low-carbon society in China. As shown in Table 3, there is a significant negative correlation between the industry development and carbon emission in the provinces of Beijing, Tianjin, Henan, Shaanxi and Qinghai. Meanwhile Tianjin is a typical old industry city in China, and its industry development path is consistent with the overall development throughout China. Therefore this paper selects Tianjin as an example for analysis.

\section{The economic and social development of Tianjin}

Tianjin, one of China's four municipalities, is a famous international port and ecological city. Tianjin is in the center of Bohai Economic Circle, the largest coastal open city in North China, the cradle of modern industry, the shipping and industrial center in North China. Being China's fourth largest industrial base and the third largest foreign trade port city, Tianjin has a rapid development in recent years with the development of Binhai New Area according to the national policy since 2006 .

Tianjin is an old industrial city and the property of the secondary industry is increased from $49.7 \%$ in 2000 to $60.1 \%$ in 2008 , but it has a great decrease of $53 \%$ in 2009 (Figure 3). The reason for the decrease is not clear; it could be due to the low carbon economy, and the relationship is what the author decided to inquire in this paper.

In the year 2009, the Government of Tianjin determined the eight competitive pillar industries, which are Aerospace Industry, Petrochemical Industry, Equipment Manufacturing, Electronic Information Industry, Bio-pharmaceutical Industry, New Energy and New Material Industry, Automobile Industry, Modern Metallurgical Industry and High-tech Textile Industry; and its production value accounts for more than $90 \%$ of the whole, especially Equipment Manufacturing Industry, Petrochemical Industry, Electric Information industry and High-tech Textile Industry which account for 49.9, 16.5, 15.1 and $12 \%$ separately (Figure 4 ).

With the development of heavy industries, the energy consumption is increased year by year, however the energy consumption for 10000 yuan Value Added is decreased (Table 4), which is opposite to the increase of industry output value. Whether is due to the changing of energy structure or not is an issue worth exploring.

\section{Industry carbon productivity in Tianjin}

Industry carbon productivity can expressed by the ratio of the industry's increase value and total carbon dioxide emissions volume, is the reciprocal of carbon intensity per unit of GDP. This indicator reflects the environment costs to be paid for in order to obtain a certain production. The measurement of industry carbon productivity of Tianjin in 2010 is shown in Table 5.

According to the carbon emissions and various industries added value published in 2010 Tianjin Statistical Yearbook, the paper calculated the industry carbon productivity.

The paper did not calculate the carbon productivity of the primary industry and the tertiary industry, for they just published added value of industry sectors in the "Tianjin Statistical Yearbook"

When it comes to the carbon productivity of the secondary industry in Tianjin, the Mining and Washing of Coal industry got highest score, reaching 852.37, that is, in order to obtain one unit of industrial added value, it will lead to 852.37 unit carbon emissions. There is a considerable big environmental cost, and the main reason for the result is that the energy input for this industry production is the electricity, which is not a primary energy affecting carbon emissions; thus the industry's annual carbon emissions is just 0.02 tons of standard coal. Therefore, carbon productivity cannot well express the environmental costs of the industry, and just according to the coefficient to choose low carbon productivity industry for industrial adjustment is one-sided.

The paper calculated the industry influence coefficient and the industry carbon emissions influence coefficient of Tianjin Province in 2007 based on the data published in the "2007 Tianjin inputoutput table".

\section{RESULTS}

According to the methodology and data source, the paper calculates the industry influence coefficient and the industry carbon emissions influence coefficient of Tianjin in 2007, and then divided the industry into four category by using matrix analysis theory, as shown in Table 6 and Figure 5, respectively.

The industries are classicized and listed in Table 7 in detail. Through the above matrix analysis, we obtained that most industry sectors of Tianjin are concentrated in the circle $A$ which is the industry that has not high industry influence and not low industrial carbon emissions influence. Among them, Equipment Manufacturing Industry, Automobile Industry and High-tech Textile Industry as the competitive pillar industries should continue to support its development, especially the Manufacture of General Purpose Machinery, Manufacture of Special Purpose Machinery, Manufacture of Transport Equipment because of its industry influence coefficient is greater than 1 and industrial carbon emissions influence coefficient is less than 1. Meanwhile, Aerospace Industry, 
Table3. The correlation between the carbon emissions intensity and changes in industrial structure in major provinces of China.

\begin{tabular}{|c|c|c|c|c|c|}
\hline No & Provinces & Primary industry $X_{1}$ & Secondary Industry $X_{2}$ & Tertiary industry $X_{3}$ & Degree of relevancy \\
\hline 0 & The national & $\begin{array}{l}-.940^{* *} \\
\text { significant negative } \\
\text { correlation }\end{array}$ & $\begin{array}{l}.965^{\star \star} \\
\text { significant positive } \\
\text { correlation }\end{array}$ & $\begin{array}{l}-.713^{*} \\
\text { negative correlation }\end{array}$ & $X_{2}>X_{1}>X_{3}$ \\
\hline 1 & Beijing & $\begin{array}{l}-.946^{\star \star} \\
\text { significant negative } \\
\text { correlation }\end{array}$ & $\begin{array}{l}-.880^{\star *} \\
\text { significant positive } \\
\text { correlation }\end{array}$ & $\begin{array}{l}.901^{* \star} \\
\text { significant negative } \\
\text { correlation }\end{array}$ & $X_{1>} X_{3}>X_{2}$ \\
\hline 2 & Tianjin & $\begin{array}{l}-.940^{\star *} \\
\text { significant negative } \\
\text { correlation }\end{array}$ & $\begin{array}{l}.954^{* *} \\
\text { significant positive } \\
\text { correlation }\end{array}$ & $\begin{array}{l}-.949^{\star *} \\
\text { significant negative } \\
\text { correlation }\end{array}$ & $X_{2>} X_{3} X_{1}$ \\
\hline 3 & Hebei & $\begin{array}{l}-.934^{\star \star} \\
\text { significant negative } \\
\text { correlation }\end{array}$ & $\begin{array}{l}.894^{\star *} \\
\text { significant positive } \\
\text { correlation }\end{array}$ & $\begin{array}{l}-.190 \\
\text { No significant } \\
\text { correlation }\end{array}$ & $X_{1>} X_{2}$ \\
\hline 4 & Shanxi & $\begin{array}{l}-.963^{\star \star} \\
\text { significant negative } \\
\text { correlation }\end{array}$ & $\begin{array}{l}.879^{\star *} \\
\text { significant positive } \\
\text { correlation }\end{array}$ & $\begin{array}{l}-.395 \\
\text { No significant } \\
\text { correlation }\end{array}$ & $X_{1>} X_{2}$ \\
\hline 5 & $\begin{array}{l}\text { Inner } \\
\text { momgolia }\end{array}$ & $\begin{array}{l}-.963^{* *} \\
\text { significant negative } \\
\text { correlation }\end{array}$ & $\begin{array}{l}.935^{\star *} \\
\text { significant positive } \\
\text { correlation }\end{array}$ & $\begin{array}{l}-.397 \\
\text { No significant } \\
\text { correlation }\end{array}$ & $X_{1>} X_{2}$ \\
\hline 6 & Liaoning & $\begin{array}{l}-.382 \\
\text { No significant } \\
\text { correlation }\end{array}$ & $\begin{array}{l}.768^{\star} \\
\text { positive correlation }\end{array}$ & $\begin{array}{l}-.809^{\star} \\
\text { negative correlation }\end{array}$ & $X_{3} X_{2}$ \\
\hline 7 & Jilin & $\begin{array}{l}-.987^{* *} \\
\text { significant negative } \\
\text { correlation }\end{array}$ & $\begin{array}{l}.620 \\
\text { No significant correlation }\end{array}$ & $\begin{array}{l}.709^{\star} \\
\text { positive correlation }\end{array}$ & $X_{3}>X_{1}$ \\
\hline 8 & Heilongjiang & $\begin{array}{l}.621 \\
\text { No significant } \\
\text { correlation }\end{array}$ & $\begin{array}{l}-.360 \\
\text { No significant correlation }\end{array}$ & $\begin{array}{l}.231 \\
\text { No significant } \\
\text { correlation }\end{array}$ & -- \\
\hline 9 & Shanghai & $\begin{array}{l}-.922^{\star \star} \\
\text { significant negative } \\
\text { correlation }\end{array}$ & $\begin{array}{l}-.124 \\
\text { No significant correlation }\end{array}$ & $\begin{array}{l}.295 \\
\text { No significant } \\
\text { correlation }\end{array}$ & $X_{1}$ \\
\hline 10 & Jiangsu & $\begin{array}{l}-.945^{\star \star} \\
\text { significant negative } \\
\text { correlation }\end{array}$ & $\begin{array}{l}.721^{*} \\
\text { positive correlation }\end{array}$ & $\begin{array}{l}.146 \\
\text { No significant } \\
\text { correlation }\end{array}$ & $X_{1>} X_{2}$ \\
\hline 11 & Zhejiang & $\begin{array}{l}-.959^{\star \star} \\
\text { significant negative } \\
\text { correlation }\end{array}$ & $\begin{array}{l}.882^{\star *} \\
\text { significant positive } \\
\text { correlation }\end{array}$ & $\begin{array}{l}.781^{*} \\
\text { positive correlation }\end{array}$ & $X_{3}>X_{2}>X_{1}$ \\
\hline 12 & Anhui & $\begin{array}{l}-.927^{\star \star} \\
\text { significant negative } \\
\text { correlation }\end{array}$ & $\begin{array}{l}.465 \\
\text { No significant correlation }\end{array}$ & $\begin{array}{l}.634 \\
\text { No significant } \\
\text { correlation }\end{array}$ & $X_{1}$ \\
\hline 13 & Fujian & $\begin{array}{l}-.977^{\star \star} \\
\text { significant negative } \\
\text { correlation }\end{array}$ & $\begin{array}{l}.919^{* *} \\
\text { significant positive } \\
\text { correlation }\end{array}$ & $\begin{array}{l}-.094 \\
\text { No significant } \\
\text { correlation }\end{array}$ & $X_{1>} X_{2}$ \\
\hline 14 & Jiangxi & $\begin{array}{l}-.926^{\star \star} \\
\text { significant negative } \\
\text { correlation }\end{array}$ & $\begin{array}{l}.968^{\star *} \\
\text { significant positive } \\
\text { correlation }\end{array}$ & $\begin{array}{l}-.966^{\star *} \\
\text { significant negative } \\
\text { correlation }\end{array}$ & $X_{2} X_{3} X_{1}$ \\
\hline
\end{tabular}


Table3. Contd.

\begin{tabular}{|c|c|c|c|c|c|}
\hline 15 & Shandong & $\begin{array}{l}-.972^{\star \star} \\
\text { significant negative } \\
\text { correlation }\end{array}$ & $\begin{array}{l}.900^{* *} \\
\text { significant positive } \\
\text { correlation }\end{array}$ & $\begin{array}{l}-.732^{\star} \\
\text { negative correlation }\end{array}$ & $X_{1>} X_{2}>X_{3}$ \\
\hline 16 & Henan & $\begin{array}{l}-.907^{\star \star} \\
\text { significant negative } \\
\text { correlation }\end{array}$ & $\begin{array}{l}.965^{\star \star} \\
\text { significant positive } \\
\text { correlation }\end{array}$ & $\begin{array}{l}-.848^{\star \star} \\
\text { significant negative } \\
\text { correlation }\end{array}$ & $X_{2} X_{3} X_{1}$ \\
\hline 17 & Hubei & $\begin{array}{l}.406 \\
\text { No significant } \\
\text { correlation }\end{array}$ & $\begin{array}{l}-.930^{\star *} \\
\text { significant negative } \\
\text { correlation }\end{array}$ & $\begin{array}{l}.916^{\star \star} \\
\text { significant positive } \\
\text { correlation }\end{array}$ & $X_{2} X_{3}$ \\
\hline 18 & Hunan & $\begin{array}{l}-.779^{\star} \\
\text { significant negative } \\
\text { correlation }\end{array}$ & $\begin{array}{l}.788^{*} \\
\text { positive correlation }\end{array}$ & $\begin{array}{l}-.406 \\
\text { No significant } \\
\text { correlation }\end{array}$ & $X_{2} X_{1}$ \\
\hline 19 & Guangdong & $\begin{array}{l}-.973^{\star \star} \\
\text { significant negative } \\
\text { correlation }\end{array}$ & $\begin{array}{l}.014 \\
\text { No significant correlation }\end{array}$ & $\begin{array}{l}.615 \\
\text { No significant } \\
\text { correlation }\end{array}$ & $X_{1}$ \\
\hline 20 & Guangxi & $\begin{array}{l}-.933^{\star *} \\
\text { significant negative } \\
\text { correlation }\end{array}$ & $\begin{array}{l}.919^{* *} \\
\text { significant positive } \\
\text { correlation }\end{array}$ & $\begin{array}{l}-.426 \\
\text { No significant } \\
\text { correlation }\end{array}$ & $X_{1>} X_{2}$ \\
\hline 21 & Chongqing & $\begin{array}{l}-.889^{\star \star} \\
\text { significant negative } \\
\text { correlation }\end{array}$ & $\begin{array}{l}.802^{*} \\
\text { positive correlation }\end{array}$ & $\begin{array}{l}.073 \\
\text { No significant } \\
\text { correlation }\end{array}$ & $X_{1>} X_{2}$ \\
\hline 22 & Sichuan & $\begin{array}{l}-.841^{\star \star} \\
\text { significant negative } \\
\text { correlation }\end{array}$ & $\begin{array}{l}.928^{\star *} \\
\text { significant positive } \\
\text { correlation }\end{array}$ & $\begin{array}{l}-.795^{\star} \\
\text { negative correlation }\end{array}$ & $X_{2}>X_{1>} X_{3}$ \\
\hline 23 & Guizhou & $\begin{array}{l}-.989^{* *} \\
\text { significant negative } \\
\text { correlation }\end{array}$ & $\begin{array}{l}.552 \\
\text { No significant correlation }\end{array}$ & $\begin{array}{l}.806^{*} \\
\text { positive correlation }\end{array}$ & $X_{1>} X_{3}$ \\
\hline 24 & Yunnan & $\begin{array}{l}.252 \\
\text { No significant } \\
\text { correlation }\end{array}$ & $\begin{array}{l}-.265 \\
\text { No significant correlation }\end{array}$ & $\begin{array}{l}.946^{* *} \\
\text { significant positive } \\
\text { correlation }\end{array}$ & $X_{3}$ \\
\hline 25 & Shaanxi & $\begin{array}{l}-.862^{* *} \\
\text { significant negative } \\
\text { correlation }\end{array}$ & $\begin{array}{l}.962^{* *} \\
\text { significant positive } \\
\text { correlation }\end{array}$ & $\begin{array}{l}-.979^{\star *} \\
\text { significant negative } \\
\text { correlation }\end{array}$ & $X_{3}>X_{2} X_{1}$ \\
\hline 26 & Gansu & $\begin{array}{l}-.937^{\star *} \\
\text { significant negative } \\
\text { correlation }\end{array}$ & $\begin{array}{l}.276 \\
\text { No significant correlation }\end{array}$ & $\begin{array}{l}.574 \\
\text { No significant } \\
\text { correlation }\end{array}$ & $X_{1}$ \\
\hline 27 & Qinghai & $\begin{array}{l}-.781^{*} \\
\text { significant negative } \\
\text { correlation }\end{array}$ & $\begin{array}{l}.945^{\star *} \\
\text { significant positive } \\
\text { correlation }\end{array}$ & $\begin{array}{l}-.961^{* *} \\
\text { significant negative } \\
\text { correlation }\end{array}$ & $X_{3}>X_{2} X_{1}$ \\
\hline 28 & Xinjiang & $\begin{array}{l}-.750^{\star} \\
\text { negative correlation }\end{array}$ & $\begin{array}{l}.945^{* *} \\
\text { significant positive } \\
\text { correlation }\end{array}$ & $\begin{array}{l}-.743^{\star} \\
\text { negative correlation }\end{array}$ & $X_{2}>X_{1>} X_{3}$ \\
\hline
\end{tabular}

**. Correlation is significant at the 0.01 level (2-tailed);*. Correlation is significant at the 0.05 level (2-tailed). Note: Associated Integrated Sequence refers to the order of the Correlation Degree.

Petrochemical Industry, Electronic Information Industry, and Modern Metallurgical Industry with the industry influence coefficient greater than 1 and the industrial carbon emissions influence coefficient greater less than 
Table 4. The energy consumption of industrial value added in Tianjin from the year 2000 to 2009 (TSC).

\begin{tabular}{lllllllllll}
\hline Year & 2000 & $\mathbf{2 0 0 1}$ & $\mathbf{2 0 0 2}$ & $\mathbf{2 0 0 3}$ & $\mathbf{2 0 0 4}$ & $\mathbf{2 0 0 5}$ & $\mathbf{2 0 0 6}$ & $\mathbf{2 0 0 7}$ & $\mathbf{2 0 0 8}$ & $\mathbf{2 0 0 9}$ \\
\hline Energy consumption & 2.26 & 2.09 & 1.94 & 1.74 & 1.67 & 1.40 & 1.35 & 1.28 & 1.16 & 1.06 \\
\hline
\end{tabular}

Table 5. Industry carbon productivity of Tianjin in 2010 (10000 yuan/tone).

\begin{tabular}{|c|c|c|}
\hline Industry Sectors & $\begin{array}{c}\text { Carbon } \\
\text { productivity } \\
\text { of Tianjin }\end{array}$ & $\begin{array}{c}\text { Carbon } \\
\text { productivity } \\
\text { of China }\end{array}$ \\
\hline Farming, Forestry, Animal Husbandry, Fishery and Water Conservancy & & 2. 53 \\
\hline Mining and Washing of Coal & 852.37 & 0.43 \\
\hline Extraction of Petroleum and Natural Gas & 2.97 & 1. 28 \\
\hline Mining and Processing of Nonmetal Ores & 3.37 & 1.50 \\
\hline Manufacture of Beverages & 4.30 & - \\
\hline Manufacture of Tobacco & 48.36 & - \\
\hline Manufacture of Textile & 2.80 & 5. 13 \\
\hline Manufacture of Textile Wearing Apparel, Footwear, and Caps & 13.20 & 1. 33 \\
\hline Manufacture of Leather, Fur, Feather and Related Products & 10.34 & - \\
\hline Printing, Reproduction of Recording Media & 7.20 & - \\
\hline Manufacture of Articles For Culture, Education and Sport Activity & 9.51 & - \\
\hline Processing of Petroleum, Coking, Processing of Nuclear Fuel & 5.88 & 0.21 \\
\hline Manufacture of Raw Chemical Materials and Chemical Products & 1.89 & 0.42 \\
\hline Manufacture of Medicines & 11.59 & - \\
\hline Manufacture of Chemical Fibers & 6.32 & - \\
\hline Manufacture of Rubber & 2.49 & - \\
\hline Manufacture of Plastics & 22.27 & - \\
\hline Manufacture of Non-metallic Mineral Products & 1.08 & 0.18 \\
\hline Smelting and Pressing of Ferrous Metals & 3.78 & 0.75 \\
\hline Manufacture of Measuring Instruments and Machinery for Cultural Activity and Office Work & 100.02 & 11. 78 \\
\hline Manufacture of Artwork and Other Manufacturing & 5.25 & 2. 52 \\
\hline Recycling and Disposal of Waste & 96.82 & 188. 02 \\
\hline Production and Distribution of Electric Power and Heat Power & 18.61 & 1.57 \\
\hline Production and Distribution of Gas & 23.10 & 0.36 \\
\hline Production and Distribution of Water & 54.40 & 6. 91 \\
\hline Construction & - & 2. 65 \\
\hline Transport, Storage and Post & - & 2. 95 \\
\hline Wholesale, Retail Trade and Hotel ,Restaurants & - & 2. 95 \\
\hline Residential Consumption & - & - \\
\hline
\end{tabular}


Table 6. The industry influence coefficient and the industry carbon emissions influence coefficient of Tianjin in 2007.

\begin{tabular}{|c|c|c|}
\hline Industry sectors & $\delta_{j}$ & $c \delta_{j}$ \\
\hline Farming, Forestry, Animal Husbandry, Fishery and Water Conservancy & 0.468 & 1.169 \\
\hline Mining and Washing of Coal & 0.654 & 2.978 \\
\hline Extraction of Petroleum and Natural Gas & 1.123 & 0.564 \\
\hline Mining and Processing of Nonmetal Ores & 0.782 & 1.150 \\
\hline Processing of Food from Agricultural Products & 0.915 & 1.139 \\
\hline Manufacture of Foods & 0.837 & 1.514 \\
\hline Manufacture of Beverages & 0.882 & 1.058 \\
\hline Manufacture of Tobacco & 0.793 & 1.036 \\
\hline Manufacture of Textile & 0.749 & 1.297 \\
\hline Manufacture of Textile Wearing Apparel, Footwear, and Caps & 1.014 & 0.687 \\
\hline Manufacture of Leather, Fur, Feather and Related Products & 1.165 & 0.538 \\
\hline Processing of Timber, Manufacture of Wood, Bamboo, Rattan, Palm, and Straw Products & 0.576 & 0.825 \\
\hline Manufacture of Furniture & 0.921 & 0.926 \\
\hline Manufacture of Paper and Paper Products & 0.848 & 1.596 \\
\hline Printing, Reproduction of Recording Media & 0.537 & 1.836 \\
\hline Manufacture of Articles For Culture, Education and Sport Activity & 0.765 & 1.168 \\
\hline Processing of Petroleum, Coking, Processing of Nuclear Fuel & 1.492 & 2.876 \\
\hline Manufacture of Raw Chemical Materials and Chemical Products & 0.987 & 2.335 \\
\hline Manufacture of Medicines & 0.568 & 1.673 \\
\hline Manufacture of Chemical Fibers & 1.104 & 2.152 \\
\hline Manufacture of Rubber & 1.038 & 2.308 \\
\hline Manufacture of Plastics & 0.961 & 1.659 \\
\hline Manufacture of Non-metallic Mineral Products & 0.572 & 2.872 \\
\hline Smelting and Pressing of Ferrous Metals & 0.741 & 1.469 \\
\hline Smelting and Pressing of Non-ferrous Metals & 1.263 & 1.562 \\
\hline Manufacture of Metal Products & 1.26 & 0.831 \\
\hline Manufacture of General Purpose Machinery & 1.046 & 0.971 \\
\hline Manufacture of Special Purpose Machinery & 1.116 & 0.858 \\
\hline Manufacture of Transport Equipment & 1.131 & 0.751 \\
\hline Manufacture of Electrical Machinery and Equipment & 1.84 & 1.787 \\
\hline Manufacture of Communication Equipment, Computers and Other Electronic Equipment & 1.657 & 0.539 \\
\hline Manufacture of Measuring Instruments and Machinery for Cultural Activity and Office Work & 0.763 & 0.915 \\
\hline Manufacture of Artwork and Other Manufacturing & 1.338 & 0.782 \\
\hline Recycling and Disposal of Waste & 0.798 & 0.957 \\
\hline Production and Distribution of Electric Power and Heat Power & 0.988 & 1.432 \\
\hline Production and Distribution of Gas & 0.741 & 1.853 \\
\hline Production and Distribution of Water & 0.446 & 0.569 \\
\hline Construction & 0.937 & 0.786 \\
\hline Transport, Storage and Post & 1.163 & 0.413 \\
\hline Wholesale, Retail Trade and Hotel ,Restaurants & 1.158 & 0.427 \\
\hline Residential Consumption & -- & -- \\
\hline
\end{tabular}

1, should pay more attention to reduce the carbon emission. Bio-pharmaceutical Industry, New Energy and New Material Industry should given a vigorous support by the government.

However, relevant government department of Tianjin should focus on the industries out of ring A. Production and Distribution of Gas industry, Manufacture of Foods,
Mining and Washing of Coal industry, Manufacture of Paper and Paper Products, Printing industry, Reproduction of Recording Media industry have low industry influence and high industrial carbon emissions influence, hence, there would be some measures to adjust or limit its development, such as introduction high-technology, increase its environment tax. 
Table 7. The detail category and its subordinated industries.

\begin{tabular}{|c|c|}
\hline Categories & Industry sector \\
\hline $\begin{array}{l}\text { High-Impact and Low- } \\
\text { Carbon } \quad \text { Emission } \\
\text { industry }\end{array}$ & $\begin{array}{l}\text { Extraction of Petroleum and Natural Gas; Manufacture of Textile Wearing Apparel, } \\
\text { Footwear, and Cap; Manufacture of Leather, Fur, Feather and Related Products; } \\
\text { Manufacture of Metal Products; Manufacture of General Purpose Machinery; Manufacture of } \\
\text { Special Purpose Machinery; Manufacture of Communication Equipment, Computers and } \\
\text { Other Electronic Equipment; Manufacture of Artwork and Other Manufacturing; Transport, } \\
\text { Storage and Post; Wholesale, Retail Trade and Hotel ,Restaurants }\end{array}$ \\
\hline $\begin{array}{l}\text { High-Impact and High- } \\
\text { Carbon } \quad \text { Emission } \\
\text { industry }\end{array}$ & $\begin{array}{l}\text { Processing of Petroleum, Coking, Processing of Nuclear Fuel; Manufacture of Chemical } \\
\text { Fibers; Manufacture of Rubber; Smelting and Pressing of Non-ferrous Metals; Manufacture } \\
\text { of Transport Equipment; Manufacture of Electrical Machinery and Equipment }\end{array}$ \\
\hline $\begin{array}{l}\text { Low-Impact } \text { and Low- } \\
\text { Carbon } \\
\text { industry }\end{array}$ & $\begin{array}{l}\text { Processing of Timber, Manufacture of Wood, Bamboo, Rattan, Palm, and Straw; } \\
\text { Manufacture of Furniture; Manufacture of Measuring Instruments and Machinery for Cultural } \\
\text { Activity and Office Work; Recycling and Disposal of Waste; Production and Distribution of } \\
\text { Water; Construction }\end{array}$ \\
\hline $\begin{array}{l}\text { Low-Impact and High- } \\
\text { Carbon } \quad \text { Emission } \\
\text { industry }\end{array}$ & $\begin{array}{l}\text { Farming, Forestry, Animal Husbandry, Fishery and Water Conservancy ; Mining and } \\
\text { Washing of Coal; Mining and Processing of Nonmetal Ores; Processing of Food from } \\
\text { Agricultural Products; Manufacture of Foods; Manufacture of Beverages; Manufacture of } \\
\text { Tobacco; Manufacture of Textile; Manufacture of Paper and Paper Products; Printing, } \\
\text { Reproduction of Recording Media; Manufacture of Articles For Culture, Education and Sport } \\
\text { Activity; Manufacture of Raw Chemical Materials and Chemical Products; Manufacture of } \\
\text { Medicines; Manufacture of Plastics; Manufacture of Non-metallic Mineral Products; Smelting } \\
\text { and Pressing of Ferrous Metals; Production and Distribution of Electric Power and Heat } \\
\text { Power; Production and Distribution of Gas }\end{array}$ \\
\hline
\end{tabular}

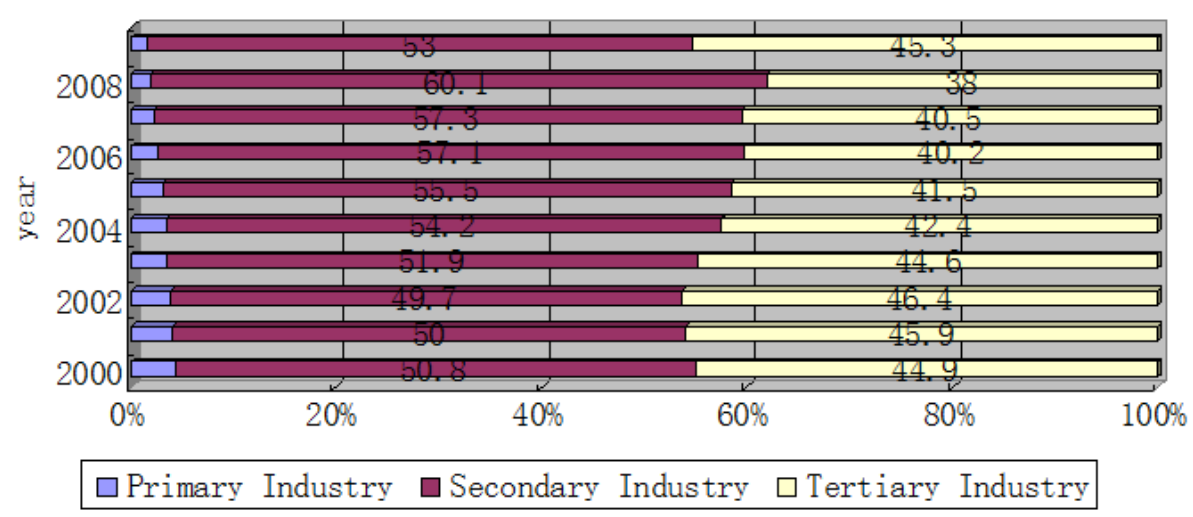

Figure 3. The changing of industry structure in Tianjin from the year 2000 to 2009.

Manufacture of Electrical Machinery and Equipment industry, Smelting and Pressing of Non-ferrous Metal industry, Manufacture of Rubber industry, Manufacture of Chemical Fibers industry, Processing of Petroleum, Coking, Processing of Nuclear Fuel industry, Manufacture of Rubber industry have high carbon emotion meanwhile high industry influence, so these industries should do more attention to decline its carbon emission by introduction progress improvement, energy structure improvement, new technology introduction and others to achieve more social efficient, environment efficient and benefit efficient.

\section{POLICY ENLIGHTMENT AND DISSCUSION}

With the rapid industrialization and urbanization, China is facing great challenges in meeting with the industrial structure imbalance related environmental and climate change issues. China's climate commitment has been focusing on carbon emission reduction, especially in large industry cities, and its policy proposal mainly focuses on the policies on industry structure, energy structure, energy intensity, carbon intensity. Despite the key policies and initiatives put forward by the general government, there are no specific instructions on how to 

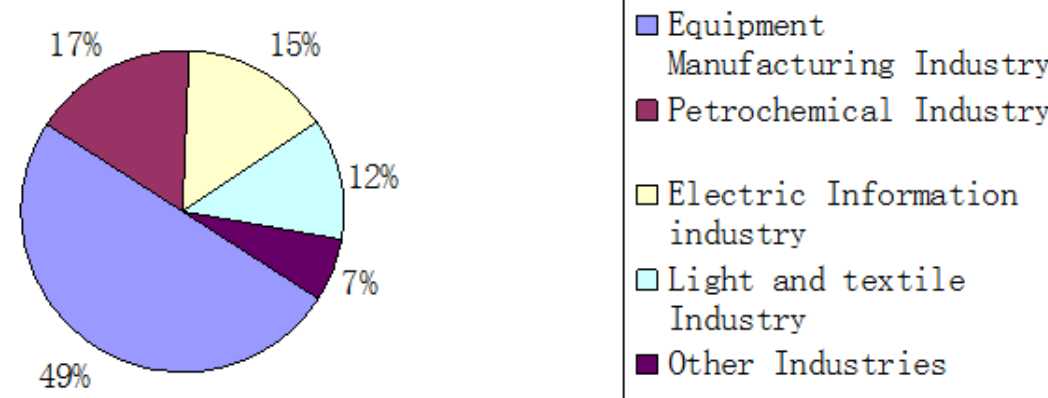

Figure 4. Composition of Tianjin competitive industry in the year 2009.

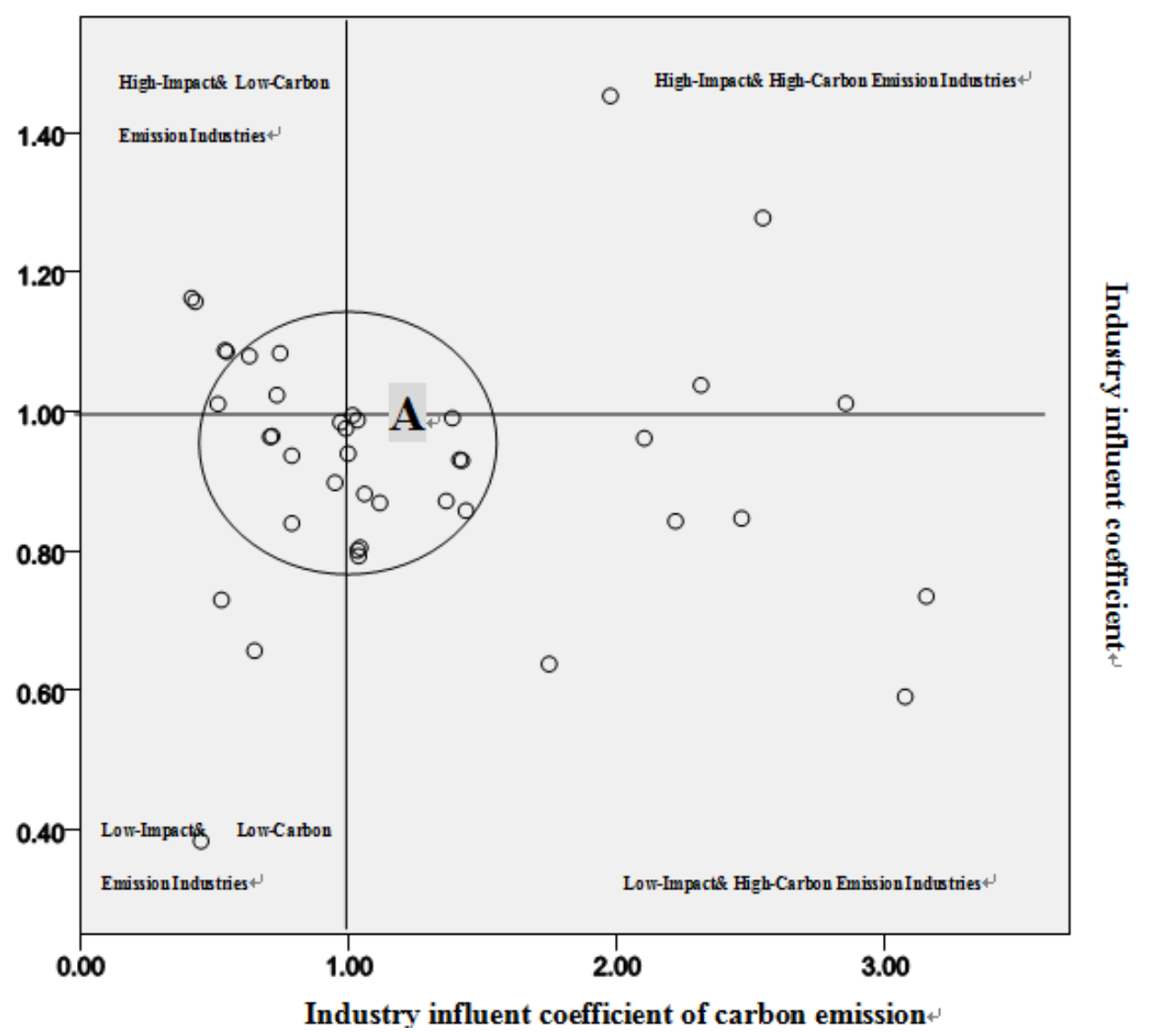

Figure 5. The matrix of Industry influent coefficient and coefficient of carbon emission and in Tianjin.

develop the optimized path for various industry sectors of each province.

Using the matrix analysis, the results show that the industry sectors which out of Circle A have high carbon emotion and low industry influence as the objects to adjust. Based on our empirical findings, we proposed the following policy recommendations to Tianjin.

First, policy should aim to change the pattern of a large share of carbon-intensive industries which out of Circle A have high carbon emotion and low industry influence through industrial structural adjustments. It should promote the industrial sectors' innovation capacity and technical diffusion. The key aims in the upgrading of industrial structure should be a high degree of processing, high technology, high added value, and low carbon. Policy needs to promote the growth of the industries which in Circle $A$ and have low carbon emotion and high industry influence, while maintaining economic growth.

Second, the measures adopted in industrial planning, 
tax policies, industrial standards, and environmental regulation must be conducive to industrial structural adjustments. Policy should encourage the use of energy saving and emission reducing technologies, and promote investment in clean energy and low-carbon technologies. Policy makers should develop low-carbon industries and promote the use of low-emitting and even zero-emitting technologies. Gradually, these recommendations can be used to build a low-carbon industrial structure.

Third, the government should do put efforts on the optimization of industry layout and coordination of regional development. With the requirements of function areas construction, the relevant department should implement different industry policies to encourage the development of competitive industries to promote the development of other low-carbon emission industries. Meanwhile, the regional departments should actively cooperate with the government to guide the industries' rational and orderly transfer, and then form a reasonable industry structure in the whole Tianjin.

Fourth, there should be guiding policies on optimal allocation of resources to improve the quality of industry development, such as, government subsidies on backward and low-carbon industries, special protection on adopting low-carbon technology industries, special protection on knowledge-intensive and technology intensive industries. Meanwhile, the government should implement policies which help fostering market players, improving the use of resource and enhancing intrinsic motivation of regional industry development.

Fifth, In the environment under the conditions of market economy, the adjustment of industrial structure has the character of endogenous, and to a considerable extent, the terminal requirements structure determines the regional industrial structure (Cai et al., 2011). Government propaganda departments should vigorously promote lowcarbon economy to develop low-carbon awareness in daily life and guide people in low-carbon lifestyle and habits.

Finally, foreign direct investment and intervention by local governments reduced carbon dioxide emissions (Zhou et al., 2013) and improved China's environmental quality in a certain extent, but the government of Tianjin should implement a higher environmental standard to selectively utilize foreign direct investment and intervention.

When it comes to the whole China, policies of industrial structure adjustment should be broader and more instructive, rather than the specific local policies. Currently China's economy is still in post-industrialization with the economic growth mainly driven by manufacturing and heavy chemical-based industry, and the lower propriety of the tertiary industry, so that there will be an economic growth still relied on over-consumption of energy and resources. If China's future economic growth still by the over-reliance on investment-driven, then the proportion of secondary industry will continue to maintain a high level; so as to the little effect on industrial structure optimization, and because of the fixed assets investment to infrastructure, construction industry-based, will increase the pressure on resources and energy and the environment. It is hard to achieve the objection of low carbon economy. Technological progress, economic structure optimization, the use of non-fossil energy sources can decline the emissions of carbon dioxide, but, generally speaking, with the tertiary industry upgrade to a certain level, there will be more perfect infrastructure, a stabilize energy and resource demand for economic development, the decreased growth of energy-intensive industries, the increased proportion of high-tech and service industry sectors. Under the guidance of national macro industry policies, such as "the National Guiding Catalog of Industrial Structure Adjustment (2012)", each province should develop and implement self industrial structure restructuring and optimizing policies in line with the regional characteristics based on provincial differences and the analysis of this paper.

The other issue to be addressed by the Chinese government is about the establishment of independent regulatory authority and responsibility over emission. It would be set emission reduction obligations for various industry sectors of each province using the methodology framework of Tianjin in this paper. Meanwhile, in order to achieve a rebalance of industrial carbon emission, the emission reduction burdens should different between well-developed provinces and less-developed provinces, at the same time different according to the correlation analysis. Besides, one national industrial carbon emission reduction target over all industrial sectors, a separate reduction target should be formulated and outlined in provincial latest five-year plan. Ideally, the provincial emission cap for each industry sectors, provincial carbon trade scheme, provincial carbon footprint, domestic clean development mechanism (CDM) can be considered.

The conclusion drawn by this study has an important reference value for the government of Tianjin to adopt relative industry strategies, and also has an important academic value in terms of enriching industrial structure adjustment and optimized path in regional level in China. However, the research is still preliminary, and many aspects need further study. For example, in order to achieve the target of reducing carbon emission as our public commitment, we will not only need to speed up the paces of industrial structure adjustment, but also need to further improve energy efficiency, to strengthen energysavings management, to promote the exploration and utilization on renewable energy through the development of a variety of clean fuel technologies and to make use of various incentive policy instruments.

\section{ACKNOWLEDGMENTS}

The authors gratefully acknowledge the support given by the National Social Science Foundation of China "The 
study on industrial structure to promote the construction of ecological civilization" (Grant No. 08BJY004) and the fund of government consultation project "Research on emission reduction incentives of promoting energy structure adjustment and industrial upgrading".

\section{REFERENCE}

Cai SH, Mou DG, Fang MX (2011). A Study on driving forces of China's industrial structure optimization under the carbon-Intensity abatement objective. Chin. J. Manage. Sci. 19(4):167-173.

Cole MA (2008). Industrial activity and the environment in china: an industry- level analysis. China Econ. Rev. (19):393-408.

Fisher Vanden K (2006). Technology development and energy productivity in China. Energy Econ. (28):690-705.

Gavin S, David A (2009). Too much of a bad thing. Nature Vol. 458.

Jefferson M (2008). Accelerating the transition to sustainable energy system. Energy Policy (36):4116-4125.

Jorgenson AK (2007). The effects of primary sector foreign investment on carbon dioxide emissions from agriculture production in lessdeveloped countries, 1980-99. Int. J. Comparat. Sociol. (1):29-42.

Lin BQ, Yao X, Liu XY (2010). China's energy strategy adjustment under energy conservation and carbon emission constrains. Soc. Sci. China (2):91-110.

Lin BQ, Jiang ZJ (2009). Estimates of the Kuznets Curve of China's $\mathrm{CO}_{2}$ environment and analysis of influencing factors. Manage. Word (4).

Liu CJ, Feng Y (2011).Low-carbon economy: theoretical study and development path choice in China. Energy Procedia (5):487-493.

Lynn P, Zhou N, David F (2013). Development of a low-carbon indicator system for China. Habitat Int. (37):4-21.

Philip KA, William B, Frank AM (2012). Carbon dioxide emissions, economic growth, industry structure, and technical efficiency: empirical evidence from Ghana, Senegal, and Morocco on the causal dynamics. Energy (47):314-325.

Shuai T, Yuan (2009). Effect of the changes of the industry structure and the energy structure in shanghai of carbon emission and the strategies for response. Resources and Environment in the Yangtze Basin (10):885-889.
Shi D (2002). The improvement in energy efficiency in China's economic growth. Econ. Res. J. (9):49-56.

Soeren L, Liu Zh, Guan DB (2013). CO2 emissions from China's power sector at the provincial level: consumption versus production perspective. Renew. Sustain. Energy Rev. (19):164-172.

Talukdar D, Meisner CM (2001). Does the private sector help or hurt the environment? Evidence from carbon dioxide pollution in developing countries. World Dev. (29):827-840.

Wang K, Zhang X, Wei YM (2013). Regional allocation of CO2 emissions allowance over provinces in China by 2020. Energy Policy (54):214-229.

Wang XX, Wang YD (2010). The problems and strategies of the low carbon economy development. Energy Procedia (5):1831-1836.

Wang YP (2009). A Study on the strategy and policy of China's industrial restructuring during the "12th Five Year Plan" period. Macroeconomics (11):3-8.

Wei BR (2007). Analysis of China's energy demand and $\mathrm{CO}_{2}$ emission scenario. Beijing: China Environment Science Press.

Xu G, Jiang Z (2007). The relationship among technical progress, structural change, and energy efficiency in the United States. Sci. Manage. Sci. Technol. (3):104-107.

Yu YH, Zheng XY, Zhang L (2011). Dioxide emission and economic development: a panel data analysis. Econ. Theory Bus. Manage. (3):72-81.

Zhou XY, Zhang J, Li JP (2013). Industrial structural transformation and carbon dioxide emissions in China. Energy Policy (57):43-51. 